\title{
ROLA KAZIMIERY GRUSZCZYŃSKIEJ I SIÓSTR FRANCISZKANEK OD CIERPIĄCYCH W OPIECE NAD BEZDOMNYMI NA PRZELOMIE XIX I XX W.
}

Jednym z problemów społecznych dziewiętnastowiecznej Warszawy, wyłaniających się z przeobrażeń politycznych, społecznych, gospodarczych i ekonomicznych było zjawisko bezdomności. Termin „bezdomny” utrwalił się w słownictwie polskim na przełomie XVIII i XIX w. Z początku kojarzony był $\mathrm{z}$ ofiarami walk powstańczych i wojen. $\mathrm{Z}$ czasem przeszedł do języka prawniczego jako określenie osób, które z różnych powodów utraciły miejsce zamieszkania. W terminologii łacińskiej określano te osoby vagantes, vagabundae, laici, co w polskim języku znaczyło: swawolnicy, wagabundzi, hultaje czy wreszcie włóczędzy ${ }^{1}$.

Zjawisko to dotykało zarówno dzieci, jak i dorosłych, starców, kaleki, nieuleczalnie chorych, osoby z marginesu społecznego, pijaków, żebraków, przestępców, prostytutki. Próbowano zaradzić mu, opisując szeroko niedolę osób bezdomnych $\mathrm{w}$ codziennej prasie, publikowanych na łamach dzienników felietonach. Opisy takie znajdujemy często też w Kronikach Bolesława Prusa i publikacjach Józefa Ignacego Kraszewskiego². Warszawa przełomu wieków była miastem pełnym kontrastów ${ }^{3}$. Organizowano bale dobroczynne i spotkania towarzyskie mające służyć pomna-

\footnotetext{
${ }^{1}$ Zob. K. P i e tr z a k - K o m a r, Wykluczenie bezdomnych, „Warmińsko-Mazurski Kwartalnik Naukowy, Nauki Społeczne”, nr 1:2015, s. 32.

${ }^{2}$ Fragment jednego z takich felietonów Prusa przytacza Międzyrzecki: „Chodzący po naszych ulicach przynajmniej parę razy w ciągu miesiąca spotkać mogą na chodniku osobę leżącą, bezprzytomną, często krwią zalaną. Jest to doprawdy jeden z najboleśniejszych żywych obrazów". Cytat za: A. M i ę dzyrze cki, Warszawa Prusa $i$ Gierymskiego. Szkice z dawnej Warszawy, Warszawa 1957, s. 81; J. B a n d ro w s k i, Najnieszczęśliwsi, Warszawa 1901, s. 8-15.

${ }^{3}$ Zob. A. M i ę d z y r z e c k i, Warszawa Prusa, passim.
} 
żaniu środków finansowych, tworzono sierocińce i przytułki ${ }^{4}$. Jedną $\mathrm{z}$ inicjatorek powstania przytułków noclegowych dla najuboższych w Warszawie była założycielka Zgromadzenia Sióstr Franciszkanek od Cierpiących, Kazimiera Gruszczyńska. Jak sama opisuje w Historii Zgromadzenia, dzięki wsparciu osób wpływowych udało się powołać do życia wiele placówek przeznaczonych dla ludzi bezdomnych. Nie było to jednak łatwe. Represje władz carskich skierowane wobec osób, zbiorowości oraz społeczeństwa, będące następstwem upadku powstania styczniowego, miały ogromny wpływ na los ludzi cierpiących, chorych a także na stan szpitalnictwa w Królestwie Polskim ${ }^{5}$.

Likwidacja autonomicznych władz, działających dotychczas instytucji, rusyfikacja administracji i powszechna cenzura były zamierzone, jako przyczynek do ujednolicenia i wprowadzania sposobu życia zintegrowanego z Cesarstwem Rosyjskim. Wszechobecna rusyfikacja Królestwa była nie tylko bolesnym doświadczeniem narodowym, ale przede wszystkim przyczyną trudności, a z czasem wręcz dramatów społeczeństwa. Migracja ze wsi do miast, brak możliwości podjęcia pracy zgodnej z wykształceniem i zubożenie to tylko część większego problemu. Wprowadzenie stanu wojennego, brak przychylności wobec instytucji społecznych i kościelnych często prowadzących działalność na rzecz ubogich i potrzebujących powodowały pogłębianie się problemów społecznych, które utrwalane przez kolejne pokolenie stały się wręcz patologiami ${ }^{6}$.

Ta, nakreślona w wielkim skrócie, kondycja kulturowa oraz sytuacja polityczna Królestwa Polskiego stały się tłem dla intensywnych przeobrażeń społecznych. Były one w znacznym stopniu prowokowane przez postępującą urbanizację, industrializację i uwłaszczenie, które szczególnie odcisnęły swoje piętno w ostatnim trzydziestoleciu XIX wieku oraz pierwszym dziesięcioleciu XX wieku ${ }^{7}$. Przybywało ludzi

\footnotetext{
${ }^{4}$ Zob. K. W a g n e r, Bale $w$ Warszawie drugiej połowy XIX w., http://www.wilanowpalac.pl/bale_w_warszawie_drugiej_polowy_xix_w.html, [25.07.2018].

${ }^{5}$ Zob. Z. C h mi e 1, Zbiórki $i$ datki dobroczynne $w$ Warszawie końca XIX wieku, http://www.wilanowpalac.pl/zbiorki_i_datki_dobroczynne_w_warszawie_konca_xix_ wieku.html, [25.07.2018].

6 Zob. A. B ołdy rew, Społeczeństwo Królestwa Polskiego wobec patologii społecznych w latach 1864-1914, Łódź 2016, s. 21; M.M. D ro z d o w s k i, A. Z a h or s k i, Historia Warszawy, Warszawa 2004, passim.

7 Zob. A. B ołd y r e w, Społeczeństwo Królestwa, s. 21; M.M. D r o z d o w s k i, A. Z a h o r s k i, Historia Warszawy, Warszawa 2004, passim.
} 
w miastach, które nie były przygotowane na ich przyjęcie. Struktury społeczne znane dotąd jako feudalne przerodziły się $\mathrm{w}$ hierarchię, w której znaczenia nabrały warstwy społeczne reprezentowane przez robotników i inteligencję. Większa część zamożnej i średniej szlachty przekształciła się w ziemiaństwo, natomiast wielu dotychczasowych ziemian, którzy nie poradzili sobie z wyzwaniami racjonalizacji gospodarki, z bagażem długów, często bankructwa, zostało zmuszonych do sprzedaży swoich majątków i migracji do miast w poszukiwaniu pracy. Uwłaszczenie i kryzys rolny zmieniły również sytuację chłopów, tworząc przepaść między najbogatszymi i najuboższymi. Część z nich pozostała bez prawa do roli, co oznaczało, że kolejna grupa ludzi musi szukać sposobu na przetrwanie w mieście. Najczęściej nie odnajdywali oni w nim swojego raju na ziemi, co często było skutkiem ich bezdomności. Rozwój przemysłu okazał się jednak korzystny dla bogatego mieszczaństwa, którego przedstawiciele prowadząc manufaktury i fabryki, przedsiębiorstwa transportowe, handlowe i ubezpieczeniowe bogacili się z roku na rok tworząc z czasem tzw. arystokrację finansową. Najmniej liczną grupę (1\% populacji) stanowiła inteligencja i choć na przełomie XIX i XX wieku aktywnie działała na niwie społecznej, to pozostała na poziomie $2 \%$ całej ludności. Z kolei w tym samym czasie dynamicznie zwiększała się liczebność robotników. Dotychczasową zbiorowość zaczęli też zasilać imigranci ze wsi ${ }^{8}$.

Dynamiczne ruchy migracyjne spowodowane sytuacją pouwłaszczeniową stały się kołem napędowym dla rozwoju demograficznego wielu zarówno większych jak i mniejszych miast Królestwa. Zmiany te dotyczyły nie tylko liczebności, ale również jakości w obszarze kulturowym. W ciągu ostatnich dziesięcioleci XIX w. Warszawa zwiększyła liczbę mieszkańców o niemal połowę, a przemysłowa Łódź o ponad $60 \%{ }^{9}$. Rozkwit industrializacji i urbanizacji dawał wiele możliwości, nietrudno się jednak domyślić, że niósł ze sobą również niemało zagrożeń. Z jednej strony dawał nadzieję na poprawę warunków życia, pracę i awans społeczny, z drugiej jednak strony osobom bez wykształcenia i niskimi kwalifikacjami groził brakiem zatrudnienia i zarobku, a w konsekwencji marginalnym ubóstwem. Niestety, ubóstwo dotykało nie tylko napływową ludność oraz osoby dziedziczące je. Biedotę zasi-

\footnotetext{
${ }^{8}$ Zob. A. B oł d y r e w, Społeczeństwo Królestwa, s. 23.

9 Zob. tamże, s. 24; M.M. D r o z d o w s k i, A. Z a h o r s k i, Historia Warszawy, passim.
} 
lali również ludzie, którzy w wyniku choroby, śmierci najbliższych (a więc sieroty i wdowy) i innych czynników losowych, stracili źródło utrzymania. Niejednokrotnie były to osoby z kręgów drobnej szlachty, zubożonego ziemiaństwa, wojskowi i nauczyciele, artyści czy wreszcie osoby uzależnione - hazardziści i alkoholicy ${ }^{10}$. To wszystko wielokrotnie prowadziło do rozwoju patologii, od bezdomności poczynając, a na prostytucji i zabójstwach kończąc. Dochodziły do tego niska jakość życia, fatalne warunki socjalno-bytowe, ograniczony dostęp do wykształcenia, kultury i opieki zdrowotnej ${ }^{11}$. Pod tym względem mieszkańcy Królestwa pozostawali daleko w tyle za krajami zachodnimi czy nawet pozostałymi zaborami ${ }^{12}$. Zjawiska te osiągnęły taki rozmiar, że konieczne stały się pomocowe akcje interwencyjne ${ }^{13}$.

${ }^{10}$ Zob. A. M i ęd z y r z e c k i, Warszawa Prusa, s. 79: „W roku 1877 znaleziono na bruku warszawskim obdartego nędzarza, osłabłego z głodu i zimna. Zmarł wkrótce w szpitalu pochowany został we wspólnej mogile najuboższych na Powązkowskim cmentarzu. Tak życie zakończył poeta Karol Pieńkowski, tłumacz Wiktora Hugo, Heinego i Musseta, słuchacz uniwersytetów w Jenie i Heidelbergu, działacz powstania styczniowego, człowiek, który zjeździł później całą Europę, biedował i snuł nadzieje, tęsknił, walczył, pisał”; „W takiej atmosferze stanęli też do walki o swoją sztukę. Walkę tę prowadzili - najzupełniej dosłownie - w łachmanach.” s. 93. W swojej publikacji Międzyrzecki wymienia wiele znanych nazwisk ludzi, którzy „w dziejach sztuki polskiej skazani byli na życie najbardziej nędzne, jakie sobie tylko można wyobrazić. Ubrani byli tak, że: „Nawet, gdy mieli pieniądze na kawę, nie wpuszczano ich ani do Lourse'a, ani do żadnej szanującej się cukierni”. „Kiedy Cyprian Godebski przyjechał z Paryża do Warszawy i, uważając to za rzecz całkiem naturalną, zaprosił do swego salonu czołowych warszawskich malarzy, ze zdumieniem ujrzano oberwańców sadzanych z szacunkiem na atłasowych fotelach”, s. 90. Tamże: „Niedaleko też, naprzeciw domu Deotymy, były salony wielkiego świata warszawskiego w pałacu Blocha, prowadzone przez żonę bankiera, Emilię z Kronenbergów - i dalej nieco, w domu Hersego, apartamenty, gdzie również zbierała się warszawska finansjera. A o kilka zaledwie kroków rozpoczynały się inne światy: przytuliska na Solcu, staromiejskich rzemieślników, bezimiennego Powiśla, bezimiennych domów przedmieścia", s. 71.

${ }^{11}$ Zob. A. M i ę d z y r z e c k i, Warszawa Prusa, s. 90. Międzyrzecki sięga do obrazów przedstawionych przez pozytywistów: „Prus wyprowadza nas z tej rozległej bezimienności na wieczorne, «zapchane publicznością» Krakowskie Przedmieście, w okolice Chmielnej i Świętokrzyskiej, gdzie na przestrzeni stu kroków można znaleźć zaspokojenie wszelkich potrzeb i przyjemności życia” - i na przedmieścia, gdzie „bruk staje się coraz gorszy, domy coraz niższe, sklepy uboższe, ludzie brudniejsi (...)”.

12 Zob. A. B ołd y r e w, Społeczeństwo Królestwa, s. 26; M.M. D r o z d o w s k i, A. Z a h o r s k i, Historia Warszawy, passim.

13 Zob. M. P ę k o w s k a, Opieka państwowa w Królestwie Polskim do 1870 roku w świetle przepisów prawnych, „Kieleckie Studia Pedagogiczne”, t. 9: 1994, s. 79. 
Do XIX wieku szpitale i przytułki w Polsce były instytucjami prowadzonymi przez Kościół, głównie przez zakony. Idąc za przykładem zachodnich instytucji, w II połowie XVIII wieku zaczęto tworzyć domy pracy dla ubogich i otwierać manufaktury w szpitalach. Powstawały pierwsze struktury opieki państwa nad ubogimi. Specjalnie powołane komisje zajmowały się dostarczaniem do pracy „ludzi luźnych" i kontrolą zakładów dobroczynnych. Działania Stanisława Augusta Poniatowskiego w kierunku udoskonalenia opieki nad ubogimi zostały przerwane przez upadek państwa polskiego ${ }^{14}$. W Królestwie Polskim obowiązek finansowania i udzielania pomocy ubogim mieszkańcom gmin nakładał dekret namiestnika cesarskiego z dnia 2 grudnia 1817 roku. Jednak pomoc ta obejmowała jedynie osoby zrejestrowane jako stali mieszkańcy gminy. W latach 1817-1832 nadzór nad działalnością opiekuńczą objęła Rada Ogólna Dozorcza przy Komisji Rządowej Spraw Wewnętrznych i Policji. 23 czerwca 1830 roku ukazało się „Prawo o włóczęgach, tułaczach i żebrakach”. Według tej ustawy, włóczęgów, tułających się i żebraków odsyłano wyrokiem właściwego sądu do placówek publicznych organizujących pracę lub do przytułków na czas od 1 do 3 miesięcy. Jeżeli w tym czasie podopieczny nie znalazł stałego źródła utrzymania, pozostawał w placówce nadal, ale nie dłużej niż 2 lata ${ }^{15}$. W 1832 roku w miejsce Rady Ogólnej Dozorczej utworzono Radę Główną Opiekuńczą (RGO), skupiającą rady szczegółowe istniejące we wszystkich szpitalach i nadzorujące instytucje charytatywne i dobroczynne. Niestety, statusy tych rad były fikcyjne $\mathrm{z}$ uwagi na brak stałych dotacji na realizacje wytyczonych zadań. Ukaz z 1842 roku włączył RGO do Komisji Spraw Wewnętrznych i Duchownych. Pod jej nadzorem znalazły się wszystkie szpitale istniejące w Królestwie. Skończyła się tym samym era znanych od średniowiecza szpitali - przytułków, skupiających pod swym dachem wszystkich ubogich, chorych i zdrowych, sieroty i żebraków. Dopiero wiec od tego momentu (1842 r.) placówki opiekuńcze zostały podzielone na szpitale - lecznice oraz przytułki dla starców, domy sierot, noclegownie, etc. a ustawa pozwalała towarzystwom dobroczynnym tylko na doraźną opiekę nad ubogimi, którzy nie zostali przyjęci do zakładów publicznych. Rok 1870 przyniósł kolejne zmiany. Władze

\footnotetext{
${ }^{14}$ Zob. M. P i ot row s k a - M a r c h e w a, Nędzarze i Filantropi. Problem ubóstwa w polskiej opinii publicznej w latach 1815-1863, Toruń 2004, s. 99.

15 Zob. M. P ę k o w s k a, Opieka państwowa, s. 81.
} 
rosyjskie zlikwidowały RGO i rady szczegółowe a powołały od początku przesiąknięte biurokracją gubernialne, powiatowe i miejskie rady dobroczynności publicznej. I choć zasiadali w nich ludzie wpływowi, to byli to przede wszystkim rosyjscy urzędnicy ${ }^{16}$.

W takich oto realiach przyszło Matce Kazimierze Gruszczyńskiej odczytywać i realizować swoje powołanie i budować struktury nowego zgromadzenia. Jej dotychczasowe doświadczenia, rygorystyczne wychowanie, wyniesiona z religijnej rodziny pobożność oraz zastana sytuacja społeczna stały się impulsem do podjęcia pracy wśród najuboższych, zarówno materialnie jak i duchowo. Posługa jej życia rozpoczęła się 1 lipca 1875 roku w Warszawie, kiedy po wstąpieniu do Zgromadzenia Posłanniczek Serca Jezusowego najpierw nabierała wśród nich ducha służby, pracując jako nauczycielka na pensji prowadzonej przez Zgromadzenie, potem kierowała Schroniskiem Nauczycielek Inwalidek przy ul. Żurawiej, a wreszcie została posłana przez o. Honorata Koźmińskiego do „Przytuliska” przy ul. Wilczej, gdzie miała zorganizować nowe zgromadzenie zakonne, o charakterze ukrytym ${ }^{17}$.

Przytulisko powstałe w wyniku działań dobroczynnych podejmowanych przez koła różańcowe miało być tymczasowym schronieniem dla nieszczęśliwych kobiet, które w wyniku perturbacji życiowych i zdrowotnych oraz braku zatrudnienia znajdowały się w sytuacji zagrożenia bezdomnością. Schronienie znajdowały tam też osoby opuszczające szpital, potrzebujące odpowiednich warunków dla poprawy swojego zdrowia. Ponieważ było to pierwsze schronisko tego typu, szybko zyskało rozgłos, a kobiet oddających się pod opiekę placówki zaczęło przybywać ${ }^{18}$.

16 Zob. M. Piotrowska-Marchewa, Nędzarze $i$ Filantropi, s. 102-103. A. B ołdyrew, Źródła do badań nad ochronkami jako instytucjami opiekuńczowychowawczymi w Królestwie Polskim w XIX i na początku XX wieku, „Ignatianum” nr 19/2: 2016, s. 271-289. Szpitale parafialne zostały przekształcone na „Domy schronienia dla starców i kalek". Szczegółowe informacje zostały zawarte w Dzienniku Praw Królestwa Polskiego: M. P ę k o w s k a, Opieka państwowa, s. 81; M. K o ś k a, Pomoc spoleczna w zaborze rosyjskim w świetle akt Rady Gtównej Opiekuńczej Szpitali 1832-1870, [w:] Nędza i dostatek na ziemiach polskich od średniowiecza po wiek $X X$, pod red. J. S z t e t yłł y, Warszawa 1992, passim.

17 Zob. M. H. M a z u re k, Powstanie i rozwój ukrytych zgromadzeń bł. Honorata Koźmińskiego w latach 1874-1908, oprac. H.I. S z u m i 1, Sandomierz 2009, passim; K. Gru s z c z y ń s k a, Historia Zgromadzenia S.S. Franciszkanek od Cierpiących, oprac. L. Czermińska, J. Marecki, s. 30-31, 44.

${ }^{18}$ Zob. H. M a r k i e w i c z o w a, Działalność opiekuńczo-wychowawcza Warszawskiego Towarzystwa Dobroczynności 1814-1914, Warszawa 2002, 117-118. Tego typu inicja- 
Po przybyciu do Przytuliska w 1882 r., Matka Kazimiera rozpoczęła działalność na rzecz utworzenia $\mathrm{z}$ kobiet $\mathrm{w}$ nim przebywających, nowej rodziny zakonnej. Oprócz pewnej drogi duchowej należało wytyczyć kierunek misji apostolskiej, jaką miały spełniać członkinie zgromadzenia. Dla Matki Kazimiery nie od razu było jasne, jak ma wyglądać jej praca i praca sióstr. Sposób realizacji tej misji, miała odczytać, idąc za słowami swojego kierownika duchowego i mentora, o. Honorata Koźmińskiego: „Niech sam Duch Święty wykaże co z was chce mieć, módlcie się aby się wykazała wola Boża" 19 .

Zgodnie z przepisami przytułku, kobiety w nim przebywające mogły wykonywać zlecone prace, a ich pensje wpływały do kasy zarządu Przytuliska. Najczęściej posyłano je do opieki nad chorymi. Jak się okazało posługa ludziom cierpiącym - wyznaczyła miejsce i zadanie nowej rodziny zakonnej w Kościele i społeczeństwie. Kazimiera Gruszczyńska bowiem, rozpoznając konieczność pracy wśród najuboższych mieszkańców Warszawy, nadal, już jako siostry cierpiących, posyłała mieszkanki Przytuliska, do opieki nad chorymi w ich własnych domach, co stało się pewnym przełomem w systemie opieki nad chorymi i cierpiącymi ${ }^{20}$.

Opinia o pełnych oddania i fachowości pielęgniarkach z Przytuliska rozszerzała się coraz bardziej i objęła swym zasięgiem również miasta poza granicami Królestwa Polskiego.

\footnotetext{
tywy, mające za zadanie zorganizowanie instytucji opiekuńczych i wychowawczych zarówno dzieci oraz tworzenie zakładów dla osób starych, nie mogących pracować, chorych i niepełnosprawnych budziło największe zainteresowanie wśród ludzi. Jednym z kluczowych zadań każdego towarzystwa dobroczynnego było zapewnienie schronienia dla tych osób. Najwięcej uwagi poświęcano problemom osób najstarszych, dlatego zazwyczaj w pierwszej kolejności, po zgromadzeniu środków finansowych, przystępowano do zakładania przytułków dla „starców i kalek” (Warszawa, Lublin, Łódź). W wielu miastach nadal działały przytułki, założone kilka wieków wcześniej (Nieszawa, Koło, Kielce, Miechów, Nowy Korczyn, Chełm, Tykocin, Płock, Wyszogród, Sandomierz). Zapewnienie opieki osobom starszym i niepełnosprawnym, nie mającym wsparcia ze strony rodziny, miało zapobiegać kolejnemu problemowi - żebractwu. Zob. A. B ołd y r e w, Społeczne inicjatywy na rzecz walki zpatologiami w Królestwie Polskim na przełomie XIX i XX w., „Studia Gdańskie”, t. 31, Gdańsk-Oliwa 2012, s. 256; C. K ę p s k i, Towarzystwa dobroczynności w Królestwie Polskim (1815-1914), Lublin 1993, passim; E. M a z u r, Dobroczynność w Warszawie XIX wieku, Warszawa 1999, passim.

${ }^{19}$ K. G r u s z c z y ń s k a Historia Zgromadzenia, s. 32.

${ }^{20}$ Zob. L. C z e r m iń s k a, Duchowość Sióstr Franciszkanek od Cierpiacych, Łódź 2009, s. 81 .
} 
Wraz z terytorialnym rozszerzaniem się działalności sióstr franciszkanek, rozszerzał się również zakres ich posługi. W końcu XIX wieku Matka Kazimiera wraz ze swoim zgromadzeniem zaczęła rozwijać nową formę służby apostolskiej: opiekę nad ludźmi opuszczonymi i bezdomnymi. Przenikliwy umysł Założycielki, umiejętność myślenia perspektywicznego oraz ogromna wrażliwość na drugiego człowieka nie pozwoliły jej przejść obojętnie wobec coraz częściej spotykanych obrazów nędzy ludzkiej. Zimą 1884 roku, idąc na mszę wieczorną do kościoła pw. św. Aleksandra w jego przedsionku zobaczyła chłopca, najwyżej kilkunastoletniego, który „drżał z zimna [...] ubranie w strzępach, niemal spadało z niego",21. Wypytując chłopca dowiedziała się, że mieszka w tzw. „Cieplarni” - noclegowni czynnej nocą dla osób bezdomnych. Jeszcze tego samego dnia, wieczorem posłała tam siostry, żeby zobaczyły, jak wygląda to miejsce. $Z$ ich relacji wynikało, że „była to nora podziemna, nieopalona. Jako oświetlenie kaganek z thuszczu, który więcej zadymiał niż oświetlał. Jedna izba - tam kobiety i mężczyźni. Ciasnota, że nikt się położyć nie mógł, tylko skulony musiał siedzieć na ziemi. W zakątku dojrzały staruszkę leżącą, cegły pod głową. Na starym rozbitym kominie dziadek prawie bez bielizny. Obraz nędzy nie do opisania i trudno do uwierzenia, aby w mieście stołecznym mogło się coś podobnego praktykować - jednak fakt" ${ }^{22}$. Kazimiera Gruszczyńska zareagowała natychmiast. Na jej polecenie, siostry przejęły opiekę nad tym miejscem, donosiły ciepłe posiłki, czasem przyprowadzały bezdomnych z Cieplarni do Przytuliska, by pozwolić się im wykąpać i dać bieliznę na zmianę. Dbały również o życie duchowe swoich podopiecznych i kiedy tylko to było możliwe przygotowywały ich do spowiedzi. Swoją służbą na rzecz ubogich w szczególny sposób odznaczała się s. Maria Kobierzycka ${ }^{23}$. Natomiast s. Helena Władzińska w swoim wspomnieniu daje świadectwo o samej Założycielce: „[Matka Kazimiera] sprawując funkcję ekonoma w «Przytulisku», miała sporo swobody, więc resztki obiadu, które pozostawały posyłała przez siostry pod kościół św. Aleksandra, gdzie w tym czasie żebrali bezdomni. Sama często do nich chodziła, zapoznając się z biedą ludzką, sprowadzała dziadków do Przytuliska, tu ich

\footnotetext{
${ }^{21}$ K. G r u s z c z y ń s k a, Historia Zgromadzenia, s. 87.

22 Tamże.

${ }^{23}$ Zob. tamże.
} 
w pralni myła, trochę przebierała i przygotowywała do spowiedzi, na którą zapraszała zwykle ks. Hr. Łubieńskiego, ówczesnego wikariusza św. Aleksandra, chociaż nieraz musiała się nasłuchać wymówek tego rodzaju: «Co ty sobie myślisz, że ja tylko od dziadów jestem?» itp., ale nigdy nie odmówił, i tak partjami wszyscy musieli się wyspowiadać, żeby dostać dobre śniadanie: słodką kawę i bułki, a trzeba ją było widzieć w tym dniu jak była rozradowana, usługując im"24.

Ponieważ sióstr cierpiących nie było stać na większą pomoc bezdomnym, Kazimiera Gruszczyńska znalazła poparcie dla tej idei wśród osób wpływowych, zaczynając od lekarzy na możnych kończąc. Opatrznościowo przybył właśnie do Warszawy na urząd oberpolicmajstra Sergiusz hr. Tołstoj, którego żona wcześniej dała się poznać w Płocku, jako filantropka. Wrażliwa na potrzeby najbiedniejszych udzieliła swego wsparcia dla idei pomocy bezdomnym na terenie Warszawy. Jak wspomina sama Matka Kazimiera, po odbyciu szeregu spotkań w warszawskim ratuszu, podjęto decyzję o ,zajęciu się tymi biedakami”. W tym celu zawiązał się Komitet składający się z osób zaufanych, do którego zaproszono: Hrabiego Skarżyńskiego, ówczesnego Prezesa Przytuliska, Anastazego Siemeńskiego, Hrabiego Feliksa Grabowskiego (późniejszy największego przyjaciela i doradcy Matki i Zgromadzenia) oraz kilka pań $\mathrm{z}$ arystokracji i ustalono, że można wykorzystać pieniądze będące w dyspozycji oberpolicmajstra, które miały służyć prowadzeniu herbaciarni dla ubogich. Wynajęto lokal na Czerniakowskiej, spisano regulamin korzystania z placówki ${ }^{25}$. Siostra Helena Władzińska tak opisała rozwój przytułków: „Ponieważ zauważono, że pomiędzy ubogiemi byli mężczyźni, którzy mogli jako tako pracować, postanowiono urządzić tak zwane domy zarobkowe. Komitet $\mathrm{z}$ panów złożony zajął się tem, co dzień wysyłano wózek konny dla zbierania starzyzny, różnych gałganów, które sortowano i odsyłano na papier. Dom zarobkowy rozwijał się pomyślnie; wyrabiano ładne słomianki itp., gospodarzem był jeden z braci (p. Sysko), mając wpływ moralny nad robotnikami"26.

Z czasem, na skutek wspólnego działania, w Warszawie powstało pięć przytułków noclegowych (na Solcu, Szerokim Dunaju, Nowolip-

\footnotetext{
${ }^{24}$ Archiwum Zgromadzenia Sióstr Franciszkanek od Cierpiących (dalej: AFC), sygn. C I, T. II-MK/67, H. W ł a d z i ń s k a, Wspomnienia, s. 74.

${ }^{25}$ Zob. K. Gru s z c z y ń s k a, Historia Zgromadzenia, s. 88; AFC, sygn. C I, T. IIMK/67, H. W ł a d z i ń s k a, Wspomnienia, s. 74-74.

${ }^{26}$ Zob. AFC, sygn. C I, T. II-MK/67, H. W ł a d z i ń s k a, Wspomnienia, s. 75.
} 
kach, przy ul. Pańskiej, na Pradze). Warunki socjalne w tych placówkach, ze względu na zaangażowanie odpowiednich osób, w porównaniu z Cieplarnią były znacznie lepsze. Bezdomni mogli korzystać z noclegów od jesieni do wiosny. Każdy przytułek musiał mieć swoją opiekunkę lub opiekuna, lekarza, który codziennie przychodził, dozorczynię, pomocnicę i posługacza. Bezdomni dostawali herbatę i porcję chleba, za które, jeśli mogli płacili dwie kopiejki, lub korzystali bezpłatnie. Jako posłanie służyły im tapczany, poduszki słomiane i derki do przykrycia. Codziennie zdawano raport, ilu przyjęto ubogich, ile wydano porcji chleba i herbaty. Na Matce Kazimierze spoczywała odpowiedzialność za opiekę pielęgniarską $\mathrm{w}$ przytułkach ${ }^{27}$. W praktyce ta opieka oznaczała niezwykle trudną pracę sióstr franciszkanek, pełną poświęcenia, a nawet ryzyka, gdyż placówki te stały się miejscem pobytu najuboższych, niejednokrotnie pijaków, włóczęgów, złodziei, żebraków i prostytutek. Ponadto należy pamiętać, że wszystko, co miało choćby pozór katolickości było traktowane, jako propaganda i surowo karane. Matka Kazimiera tak opisała pracę sióstr, na przykładzie ich posługi w przytułku na Pradze: „Gdy to piszę, przychodzą mi na myśl, że dziś nigdy bym się nie zdecydowała, aby dać siostry w takich warunkach. Ów park, to miejsce bandytów, złodziei, rozbójników. Przychodzili na ten nocleg z nożami w zanadrzu (byli tam i poczciwi, a biedni), ścigani przez policję, często aresztowani. Ten przytułek był najliczniejszy, do 100 łóżek. Pracę miały dość ciężką. $Z$ rana po wyjściu ubogich oczyszczanie łóżek, koców z robactwa, itp." ${ }^{28}$.

Siostry z miłością opiekowały się bezdomnymi, organizowały wieloraką pomoc, a także zbierały datki w naturze. Na tę dobroczynną inicjatywę franciszkanek hojnie odpowiadali darczyńcy. Jak pisze sama Kazimiera Gruszczyńska, któregoś roku w Boże Narodzenie stoły były pełne ryb, a w Wielkanoc obfite w najlepsze mięsa ${ }^{29}$. Ta heroiczna praca franciszkanek na rzecz najuboższym została podkreślona także przez mecenasową Marię Wrotnowską, co zostało zapisane we wspomnieniu o jej zaangażowaniu filantropijnym, przeplatającym się raz po raz z działalnością Matki Kazimiery ${ }^{30}$.

\footnotetext{
${ }^{27}$ Zob. K. G r u s z c z y ń s k a, Historia Zgromadzenia, s. 89-90.

${ }^{28}$ Tamże, s. 89-90.

${ }^{29}$ Zob. tamże, s. 90.

${ }^{30}$ Zob. Krótkie wspomnienie o Marji z Tabęckich mecenasowej Wrotnowskiej, Warszawa, 1910, s. 16-19.
} 
Mimo tak owocnej pracy, pobyt bezdomnych w przytułkach noclegowych zorganizowanych z inicjatywy Kazimiery Gruszczyńskiej musiał się zakończyć. Jak opisuje Matka, wraz z przybyciem do Warszawy generała Iosifa Władimirowicza Hurki znanego w historiografii, jako jeden z najsroższych rusyfikatorów Królestwa Polskiego, odebrano prowadzącym przytułki możliwość zajmowania się ubogimi, skonfiskowano inwentarz, a zarząd nad placówkami przejęła generałowa Maria Andrejewna. Zbudowano przemyślane przytułki noclegowe, a przy nich tanie kuchnie oraz dano możliwość podejmowania drobnych zajęć zarobkowych. Po części zajęli się tym albertyni, co Matka Kazimiera uznała za Bożą opatrznośćci

Działalność Matki Kazimiery i sióstr cierpiących na rzecz ubogich i bezdomnych nie ograniczała się jedynie do stolicy. Poza Warszawą, w Królestwie Polskim oraz poza jego granicami, pomoc dla bezdomnych często była związana z posługą sióstr w szpitalach i przytułkach. Przy tych placówkach prowadzone były tanie kuchnie, herbaciarnie, jak np. w szpitalu w Zgierzu ${ }^{32}$. W Poznaniu w latach 1884-1894 opieka nad starymi, często bezdomnymi ludźmi stała się głównym zadaniem Zgromadzenia. Siostra Helena Władzińska tak opisuje to miejsce: „Ile tam siostry okazały poświęcenia, ofiary z siebie, w warunkach najcięższych, gdzie woda zamarzała w miednicy" "33. Również tam siostry zorganizowały i prowadziły tanią kuchnię dla biednych ${ }^{34}$. Natomiast w Odessie w latach 1884-1898, siostry m.in. opiekowały się ubogimi i starcami w tzw. „Domu Kościelnym”. Schronisko dla ubogich mieściło 40 osób. Początki tego domu były bardzo trudne, ale siostry chętnie tam pracowały, co zaowocowało zaufaniem ubogich. Wśród „przytulonymi” wiele osób pochodziło z inteligencji z powstania styczniowego, jak np. Zwierowiczowa z dwoma córkami, 90-letnia staruszka, która straciła w powstaniu męża oraz dwóch synów na wyższych wojskowych stanowiskach i cały majątek ${ }^{35}$. Również w Krasławiu franciszkanki odwiedzały chorych biedaków i opiekowały się miejscowymi Łotyszami. Natomiast w Wilnie, dzięki fundacji

${ }^{31}$ Zob. K. Gru s z c z y ń s k a, Historia Zgromadzenia, s. 90.

${ }^{32}$ Zob. AFC, sygn. C I, T. I-MK/5, K. Gru s z c z y ń s k a, Sprawozdanie o stanie Zgromadzenia wysłane do Ojca Honorata, 1897-1906, s. 9.

${ }^{33}$ AFC, sygn. C I, T. II-MK/67, H. W ł a d z i ń s k a, Wspomnienia, s. 73.

${ }^{34}$ Zob. K. G r u s z c z y ń s k a, Historia Zgromadzenia, s. 97-98.

${ }^{35}$ Zob. AFC, sygn. C I, T. II-MK/67, H. W ł a d z i ń s k a, Wspomnienia, s. 75. 
ks. Wiktora Frąckiewicza powstał przytułek dla nieuleczalnie chorych $^{36}$. W Zelcach koło Odessy w 1902 roku założono przytułek dla ubogich. Dom wybudowany specjalnie na ten cel był duży, pięknie położony, dobrze urządzony przez siostry, które się wszystkim zajmowały. W wyznaczonym dniu sprowadzono biednych: kobiety, mężczyzn, dzieci, łącznie kilkanaście osób i rozpoczęto nową misję ${ }^{37}$. W 1926 roku z inicjatywy Matki Kazimiery powstał kolejny dom z przeznaczeniem na przytułek. Gromadził on niedołężne i ubogie staruszki. Założony został w majątku Grzybowszczyzna, powiat Nieśwież, po przekazaniu go na rzecz Zgromadzenia przez siostrę Elżbietę Broniewskąą . W latach 1920-1930 stale przebywało tam 315 ubogich kobiet ${ }^{39}$.

Pod koniec XIX wieku Kazimiera Gruszczyńska, w odpowiedzi na prośbę mecenasowej Marii Wrotnowskiej, włączyła się również w pomoc nieuleczalnie chorym na terenie Warszawy ${ }^{40}$. Matka czynnie

\footnotetext{
${ }^{36}$ Zob. Tamże, s. 75-76.

${ }^{37}$ Zob. K. Gr u s z c z y ń s k a, Historia Zgromadzenia, s. 84.

${ }^{38}$ Zob. AFC, sygn. C I, T. II-MK/92, W. B u r s i a k, Życiorys śp. Czcigodnej Matki
} Kazimiery Gruszczyńskiej Założycielki ukrytego Zgromadzenia Sióstr Franciszkanek od Cierpiących w Warszawie, t. II, s. 146-161.

39 Zob. D. O 1 s z e w s k i, W stużbie cierpiacym. Charyzmat Kazimiery Gruszczyńskiej (1848-1927), Niepokalanów 1991, s. 139.

40 Zob. J. B a n d row s k i, Najnieszczéśliwsi, Warszawa 1901, s. 19; L. C z e r $\mathrm{m}$ iń s k a, Wszystko zaczęło się w Kozienicach. Życie i dzieło Stugi Bożej Kazimiery Gruszczyńskiej (1848-1927), Kozienice 2017, s. 69. W 1889 roku mecenasowa otwarła na Tamce 45 „Pierwsze Ambulatorium bezpłatne dla biednych chorych z ranami”. Wkrótce powstały kolejne, w sumie cztery, z czego ostatnie, na ul. Ogrodowej przekształciło się w szpitalik dziecięcy. Ostatnim dziełem życia filantropki, Wrotnowskiej było powstanie Towarzystwa Opieki nad Nieuleczalnie Chorymi. Prezesem Stowarzyszenia był Adam hrabia Zamoyski, a jednym z członków Rady Opiekuńczej była Kazimiera Gruszczyńska. Impulsem do stworzenia tej instytucji stała się prośba hrabiny Augustowej Potockiej, która, sama angażując się w działalność dobroczynną, poprosiła mecenasową o zaopiekowanie się żebraczką spod kościoła św. Krzyża, oferując odpowiednią kwotę na jej utrzymanie i opiekę. Biedaczka ta, chora na raka, trafiła do Ambulatorium na Tamce, gdzie wynajęto dla niej przylegający pokój i oddano pod opiekę franciszkanki, infirmerki kierującej lecznicą. Historia podaje nawet nazwisko tej żebraczki - Lenkiewicz. Wkrótce dołączyła do niej kolejna uboga kobieta z polecenia Zofii Górskiej i tak powstał pierwszy przytułek dla nieuleczalnych, obsługiwany przez duchowe córki Kazimiery Gruszczyńskiej. W 1893 roku, po zebraniu odpowiednich środków finansowych Wrotnowska doprowadziła do powstania Przytułku dla Rakowatych, wynajmując od Maternity mały drewniany domek przy ul. Wspólnej 69, mogący pomieścić 12 łóżek. Zarząd gospodarczy i opiekę pielęgniarską, pod nadzorem swej Założycielki, objęły w nim siostry z Przytuliska. Po kilku latach, po śmierci Augu- 
zaangażowała się bowiem w działalność Towarzystwa Opieki nad Nieuleczalnie Chorymi, którego celem było stworzenie sytemu opieki nad ludźmi dotkniętymi chorobą nowotworową. Nie brakowało wśród bezdomnych, niemających rodziny, zdeprawowanych, stanowiących margines społeczny. We wszystkich lecznicach i ambulatoriach założonych dla nieuleczalnych posługiwały siostry z Przytuliska, co było oceniane, jako gwarancja ładu, porządku i wzorowej czystości ${ }^{41}$.

W działalności Kazimiery Gruszczyńskiej na rzecz pomocy bezdomnym nie można pominąć także posługi sióstr w warszawskim szpitalu dla ubogich matek. Również tę placówkę Matka tworzyła z pomocą Marii Wrotnowskiej. Z jej inicjatywy bowiem powstało towarzystwo opieki nad ubogimi matkami i ich dziećmi, tzw. Maternita, które zajmowało się kobietami w ciąży, biednymi, często prostytutkami i bezdomnymi. Kiedy Maternita przekształciła się w szpital dla ubogich matek, Wrotnowska powierzyła zarząd wewnętrzny i opiekę nad przebywającymi tam kobietami i ich dziećmi siostrom z Przytuliska ${ }^{42}$.

Tak więc, odpowiadając na głos Ducha Świętego oraz znaki czasu, w którym przyszło jej realizować swoje powołanie, Matka Kazimiera oraz siostry franciszkanki ze zgromadzenia przez nią założonego, odgrywały ogromną, jeśli nie kluczową rolę w opiece nad bezdomnymi na przełomie XIX i XX wieku. Oprócz opieki i troski o codzienny byt, przywracały swoim podopiecznym prawo do godnego życia, a nawet godnego odchodzenia ze świata.

Patrząc na działalność Kazimiery Gruszczyńskiej możemy zobaczyć, jak wiele społeczeństwo, a przede wszystkim najubożsi jego członkowie, zawdzięcza jej determinacji, mądrości i otwartości na działanie Ducha Świętego. W swojej wrażliwości pozostała nieugięta pomimo trudności, które zewsząd ją otaczały. Tworząc nowe zgromadzenie zburzyła mur nieufności świeckiego zarządu Przytuliska, obroniła siebie i siostry przed wszechobecną inwigilacją ze strony zaborcy,

stowej Potockiej, egzekutorzy jej majątku przeznaczyli 20000 rubli na nieuleczalnych a hrabia Zygmunt Pusłowski ofiarował Towarzystwu dom z kościółkiem za Mokotowem, przylegający do posiadłości pałacowej, zwanej Królikarnią. Dom ten nazywany był Królikarnią B. Mógł przyjąć 40 nieuleczalnie chorych. Krótkie wspomnienie o Marji z Tabęckich mecenasowej Wrotnowskiej, Warszawa 1910, s. 33-40.

${ }^{41}$ Zob. tamże, s. 31-32; J. B a n d r o w s k i, Najnieszczęśliwsi, s. 8-15.

42 Zob. Krótkie wspomnienie, s. 20-22; D. O $1 \mathrm{~s} \mathrm{z} \mathrm{e} \mathrm{w} \mathrm{s} \mathrm{k} \mathrm{i,} \mathrm{W} \mathrm{stużbie} \mathrm{cierpiacym,}$ s. 133-134. 
nie poddała się pomimo przedłużającego się czasu oczekiwania na zatwierdzenie statutów zakonnych przez Stolicę Apostolską. Przez 45 lat (1882-1927) czuwała nad Zgromadzeniem Sióstr Franciszkanek od Cierpiących. Jej działania były wyrazem bezgranicznej miłości wobec osób zepchniętych na margines społeczny przez chorobę, ubóstwo, sieroctwo i bezdomność. Dla niej prośba o pomoc ze strony cierpiącego człowieka była prośbą kierowaną przez samego Chrystusa ${ }^{43}$. Owocem jej pracy, jako przełożonej Zgromadzenia było powstanie ponad dwudziestu placówek dla cierpiących. Wyznacznikiem zaangażowania sióstr był przede wszystkim zakres ludzkiego cierpienia. Stąd też ich obecność wśród najuboższych stała się odpowiedzią na problemy społeczne, będące skutkiem przemian społecznych i gospodarczych w drugiej połowie XIX wieku w Warszawie i Królestwie Polskim ${ }^{44}$.

\footnotetext{
${ }^{43}$ Zob. AFC, sygn. B VI, T. I-Wizyt/6, Księga zarządzeń po przeprowadzonych wizytacjach w Wilnie 1907-1912, s. 4-5.

${ }^{44}$ Zob. L. C z e r m i ń s k a, Wszystko zaczęto się, s. 63.
} 


\section{Bibliografia}

\section{Źródła archiwalne}

Archiwum Zgromadzenia Sióstr Franciszkanek od Cierpiących (AFC):

- sygn. B VI, T. I-Wizyt/6, Księga zarządzeń po przeprowadzonych wizytacjach w Wilnie 1907-1912

- sygn. C I, T. I-MK/5, K. G r u s z c z y ń s k a, Sprawozdanie o stanie Zgromadzenia wysłane do Ojca Honorata, 1897-1906

- sygn. C I, T. II-MK/67, H. W ł a d z i ń s k a, Wspomnienia

- sygn. C I, T. II-MK/92, W. B u r si a k, Życiorys śp. Czcigodnej Matki Kazimiery Gruszczyńskiej Założycielki ukrytego Zgromadzenia Sióstr Franciszkanek od Cierpiących w Warszawie, t. II.

\section{Źródła drukowane}

Gruszczyńska K., Historia Zgromadzenia S.S. Franciszkanek od Cierpiacych, oprac. L. Czermińska, J. Marecki, Kraków 2019.

\section{Opracowania}

Bandrowski J., Najnieszczęśliwsi, Warszawa 1901.

Bołdyrew A., Społeczeństwo Królestwa Polskiego wobec patologii społecznych w latach 1864-1914, Łódź 2016.

Bołdyrew A., Spoleczne inicjatywy na rzecz walki z patologiami w Królestwie Polskim na przelomie XIX i XX w., „Studia Gdańskie”, t. 31, GdańskOliwa 2012.

Bołdyrew A., Źródła do badań nad ochronkami jako instytucjami opiekuńczowychowawczymi w Królestwie Polskim $w$ XIX $i$ na początku XX wieku, „Ignatianum” nr 19/2: 2016.

Czermińska L., Duchowość Sióstr Franciszkanek od Cierpiacych, Łódź 2009. Czermińska L., Wszystko zaczęto się w Kozienicach... Życie i dzieto Stugi Bożej Kazimiery Gruszczyńskiej (1848-1927), Kozienice 2017.

Drozdowski M.M., Zahorski A., Historia Warszawy, Warszawa 2004.

Kępski C., Towarzystwa dobroczynności w Królestwie Polskim (1815-1914), Lublin 1993.

Kośka M., Pomoc spoteczna w zaborze rosyjskim w świetle akt Rady Gtównej Opiekuńczej Szpitali 1832-1870, [w:] Nędza i dostatek na ziemiach polskich od średniowiecza po wiek XX, pod red. J. Sztetyłły, Warszawa 1992.

Krótkie wspomnienie o Marji z Tabęckich mecenasowej Wrotnowskiej, Warszawa, 1910.

Markiewiczowa H., Działalność opiekuńczo-wychowawcza Warszawskiego Towarzystwa Dobroczynności 1814-1914, Warszawa 2002.

Mazur E., Dobroczynność w Warszawie XIX wieku, Warszawa 1999. 
Międzyrzecki A., Warszawa Prusa i Gierymskiego. Szkice z dawnej Warszawy, Warszawa 1957.

Olszewski D., W stużbie cierpiącym. Charyzmat Kazimiery Gruszczyńskiej (1848-1927), Niepokalanów 1991.

Pękowska M., Opieka państwowa $w$ Królestwie Polskim do 1870 roku w świetle przepisów prawnych, „Kieleckie Studia Pedagogiczne”, t. 9: 1994. Pietrzak-Komar K., Wykluczenie bezdomnych, „Warmińsko-Mazurski Kwartalnik Naukowy, Nauki Społeczne", nr 1:2015.

Piotrowska-Marchewa M., Nędzarze i Filantropi. Problem ubóstwa w polskiej opinii publicznej w latach 1815-1863, Toruń 2004.

\section{Strony internetowe}

Wagner K., Bale $w$ Warszawie drugiej polowy XIX w., http://www.wilanowpalac.pl/bale_w_warszawie_drugiej_polowy_xix_w.html, [dostęp: 25.07.2018]. Chmiel Z., Zbiórki i datki dobroczynne w Warszawie końca XIX wieku, http://www.wilanowpalac.pl/zbiorki_i_datki_dobroczynne_w_warszawie_ konca_xix_wieku.html, [dostęp: 25.07.2018].

ANETA KOZAK

\section{ROLA KAZIMIERY GRUSZCZYŃSKIEJ I SIÓSTR FRANCISZKANEK OD CIERPIĄCYCH W OPIECE NAD BEZDOMNYMI NA PRZELOMIE XIX I XX W.}

Streszczenie: Warszawa przełomu wieków to miasto pełne kontrastów. Z jednej strony przeobrażenia polityczne, społeczne, gospodarcze i ekonomiczne wpływały na rozwój aglomeracji miejskiej, z drugiej natomiast zauważa się narastanie problemów, które można określić, jako patologie społeczne. Z pewnością do nich można zaliczyć zjawisko bezdomności. Na ulicach XIX-wiecznej stolicy można było zauważyć wielu włóczęgów, żebraków, tułaczy, pijaków, prostytutki, często też dzieci, nie mających dachu nad głową. Chcąc zainteresować szersze środowisko losem tych ubogich, przedstawiano ich trudną sytuację, opisując ją w codziennej prasie, w publikowanych na łamach dzienników felietonach czy kronikach. Szukano także rozwiązań dla niedoli ludzi dotkniętych bezdomnością, tworząc dla nich m.in. czasowe przytułki, organizując miejsca pracy, tanie kuchnie czy herbaciarnie. Jedną z inicjatorek powstania przytułków noclegowych dla najuboższych w Warszawie była założycielka Zgromadzenia Sióstr Franciszkanek od Cierpiących, Kazimiera Gruszczyńska. Dzięki jej staraniom, losem osób bezdomnych na terenie Warszawy, udało się zainteresować arystokrację, także działaczy społecznych oraz urzędników rządowych. W wyniku wspólnie pojętych działań, z inicjatywy Matki Kazimiery, w stolicy utworzono pięć przytułków dla najuboższych: na Pradze, na Szerokim Dunaju, na Pańskiej oraz na 
Solcu. We wszystkich przytułkach bezdomnymi opiekowały się siostry franciszkanki od cierpiących.

Praca sióstr franciszkanek od cierpiących w przytułkach zakończyła się wraz z przybyciem do Warszawy generała Iosifa Władimirowicza Hurki. Wówczas odebrano siostrom możliwość zajmowania się tymi biedakami, skonfiskowano inwentarz, a zarząd nad placówkami przejęła żona generała. Dla bezdomnych zbudowano przemyślane przytułki noclegowe, utworzono tanie kuchnie oraz dano możliwość podejmowania drobnych prac zarobkowych. Po części opieką nad „ludźmi ulicy” zajęli się także albertyni.

Słowa klucze: bezdomność, przytułki noclegowe, Kazimiera Gruszczyńska, działalność dobroczynna.

\title{
THE ROLE OF KAZIMIERA GRUSZCZYŃSKA AND THE FRANCISCAN SISTERS OF SUFFERING IN THE CARE FOR THE HOMELESS AT THE TURN OF THE $19^{\mathrm{TH}}$ AND $20^{\mathrm{TH}}$ CENTURIES
}

\begin{abstract}
Warsaw at the turn of the centuries was a city full of contrasts. On the one hand, political, social and economic transformations influenced the development of the urban agglomeration, on the other, there was a growing problem that can be described as social pathologies. Certainly, the phenomenon of homelessness was one of them. In the streets of the nineteenth century capital, one could see many tramps, beggars, wanderers, drunkards, prostitutes, often children who had no roof over their heads. To interest wider circles in the fate of these poor people, their difficult situation was presented in the daily press, in the published articles and chronicles. Solutions were also sought by creating temporary shelters, organizing workplaces, cheap kitchens or tea rooms. One of the initiators of the creation of shelters for the poorest in partition-era Warsaw was the founder of the Congregation of the Franciscan Sisters of Suffering, Kazimiera Gruszczyńska. Thanks to her efforts, wider circles of aristocracy, social activists and government officials became interested in the fate of homeless people in Warsaw. As a result of joint actions, at the initiative of Mother Kazimiera, five poorhouses were created in the capital: in Praga, in Szeroki Dunaj, Pańska Street and Solec. In all the shelters the homeless were looked after by the Franciscan Sisters of Suffering.

The work of the Franciscan Sisters of Suffering in the shelters ended with the arrival of General Iosif Vladimirowicz Hurko to Warsaw. At that time, the sisters were deprived of the opportunity to take care of the poor people, the inventory was confiscated, and the management of the facilities was taken over by the General's wife. Overnight shelters and cheap kitchens were built for the homeless, and they were given the opportunity of undertaking small profitable jobs. In part, Albertine Brothers took care of "street people".
\end{abstract}

Keywords: homelessness, overnight shelters, Kazimiera Gruszczyńska, charity. 
